\title{
A technomorphological and functional study of Late Pleistocene and Middle Holocene lithic assemblages from Patagonia Argentina
}

\author{
Manuel Cueto $^{\mathrm{a}, \mathrm{b}, *}$, Ariel D. Frank ${ }^{\mathrm{a}, \mathrm{b}}$, Alicia Castro ${ }^{\mathrm{c}}$ \\ a CONICET, Argentina \\ ${ }^{\mathrm{b}}$ Facultad de Ciencias Naturales y Museo, Universidad Nacional de La Plata, Edificio Anexo, Laboratorio 107, Calle 60 y 122 S/N (1900), La Plata, Buenos \\ Aires, Argentina \\ ${ }^{c}$ División Científica de Arqueología, Museo de Ciencias Naturales, Universidad Nacional de La Plata, Paseo del Bosque S/N (1900), La Plata, Buenos Aires, \\ Argentina
}

\section{A R T I C L E I N F O}

\section{Article history:}

Available online 20 May 2016

\section{Keywords:}

Functional analysis

Contextual approach

Lithic assemblages

Late Pleistocene

Middle Holocene

Patagonia Argentina

\begin{abstract}
A B S T R A C T
In this paper, we analyze the lithic assemblages from three sites from the Central Plateau of Santa Cruz in the Argentine Patagonia. Functional analysis was combined with a techno-morphological and distributional approach, the investigation on raw materials and the study of the technological strategies of production and consumption. The significance of combining functional analysis with other research methods involving lithic remains is emphasized. By articulating different methodologies, it is possible to understand the systems of technological organization.

Two sites refer to Final Pleistocene occupations (Cerro Tres Tetas 1 and Casa del Minero 1). The integration of approaches showed the diversity of strategies developed in the production and use of tools, as well as the existence of activity areas within the sites. The third site is a Middle Holocene context (Cueva 13 of Los Toldos). The combination of perspectives allowed a redefinition of the toolkit structure and showed that blade production was part of a standardized technological system.
\end{abstract}

() 2016 Elsevier Ltd and INQUA. All rights reserved.

\section{Introduction}

During the middle of the 20th century, technological studies became important as a means of reconstructing tool production processes and function. Observation methods were developed, making it possible to recognize how tools were used (Semenov, 1964). During the last decades, functional analysis has expanded. It is now applied within the study of the technological organization of societies (Roebroeks et al., 1997; van Gijn, 2003; Banks, 2004).

Functional analysis helps researchers to understand different types of socio-economical organizations and the historical context in which they develop. In order to answer these issues, it should be carried out in conjunction with other avenues of research. It is necessary to articulate functional analysis with the technomorphological study of the assemblages, the investigation regarding the properties and availability of the raw materials,

\footnotetext{
* Corresponding author. Facultad de Ciencias Naturales y Museo, Universidad Nacional de La Plata, Edificio Anexo, Laboratorio 107, Calle 60 y 122 S/N (1900), La Plata, Buenos Aires, Argentina.

E-mail addresses: manuelcueto@fcnym.unlp.edu.ar (M. Cueto), frank.ariel@ gmail.com (A.D. Frank), aliciacastro52@gmail.com (A. Castro).
}

spatial organization and the study of the technological strategies of production and use (Odell, 1981; Geneste, 1991; Álvarez, 2003; Briz, 2010). Through combining these different methods, substantial interpretations about past societies can be generated.

In this context, the goal of this article is to analyze Late Pleistocene and Middle Holocene stone assemblages from the Central Plateau of Santa Cruz, Argentine Patagonia, in order to discuss the strategies of production and consumption of the societies. Microscopic based functional analysis was combined with other methodological avenues and inserted into larger contextual investigations related to the technological organization of human groups.

\section{A contextual view of functional analysis}

In this paper functional analysis is integrated to the study of technological organization. From this perspective, it is believed that economic, social, and environmental factors affect the strategies which guide the technological component of human behavior (Bamforth, 1991; Nelson, 1991; Dobres and Hoffman, 1994; Terradas, 2001). 
The investigations conducted by the authors evaluate the processes of production and consumption of lithic artifacts in specific spatiotemporal contexts. The goal is to reconstruct technological strategies and to interpret why the organization of lithic production takes particular characteristics in different contexts.

Every archaeological artifact is the materialization of social relations of production and consumption, which are the forces that shape a society (Briz, 2006-2007). Every tool is the final product of a manufacturing process as well as an implement which will be used in another process. Tools can be regarded as having two hemispheres: one is defined by how it was made, the other one by what it was made for.

The how hemisphere includes the raw material, the way it was acquired, the ideas about how the object should be made and the techniques and gestures that enable the idea to become material (Nami, 1986; Pelegrin et al., 1988; Geneste, 1991; Andrefsky, 2005). At the same time, these factors are affected by the practical needs, stylistic traditions, skills and knowledge of the societies (Ingold, 1997; Álvarez, 2003).

Lithics retain evidence of the succession of gestures carried out prior to their own detachment. Hence, it becomes possible to reconstruct knapping processes, techniques, and the aims of the actors (Tixier et al., 1980; Apel, 2008; Álvarez et al., 2008). Technomorphological analyses should be oriented towards the detection of possible relationships between a set of features understood as products of human work - in order to identify which morphological traits are relevant for each stage of production and for the use of a given tool (Boëda et al., 1990; Briz, 2006-2007).

The what for hemisphere implies the utilitarian or symbolic use of an object and the type of functions it had. Since each tool is manufactured for certain purposes, its design must fulfill minimum requirements to carry out that activity. For instance, the macroscopic characteristics of the artifacts (size, shape, presence of backed dorsal faces or stems) and edges (angle, length and shape) should be analyzed in order to understand the variability in the relationship between shape and function of the tools. These features, together with microscopic observations, can show if a certain kind of artifact/edge was used on a regular basis for a specific function. At the same time, relationships can be established, between the size of the tool, the fragility of the raw material and the processing of materials with specific characteristics (size, hardness). Besides, it is possible to identify if there are functional relationships between certain parts of the tools (stems, notches, flutes, necks) and specific use-wear traces. This helps to know if the tool was hafted (Odell, 1981; Finlayson and Mithen, 1997; Rots, 2010) or how the tool was hold while it was used. Therefore, this approach enables the reorientation of the research focus towards different scales of analysis (the edge, the tool, the assemblage) and to identify significant relationships at different levels which respond to technological factors (Briz, 2004).

Both the traces of the manufacture and use of an artifact can be regarded as the material traces of socially organized work. Work is developed in different places across the territory of a given society. The use of diverse spaces, both in the intrasite and regional scales, can differ due to several reasons such as the uneven distribution of resources or the way production tasks are socially organized. In this sense, there is a hierarchy of spaces for each society. As manufacture and use of tools are inevitably tied, it is possible to state that spatial analyses can link both hemispheres, by tracing the life of the artifacts, from the acquisition of the raw material until their discard and deposition. In other words, they help to understand how work is structured within a society. Therefore, in order to understand the issues linked to the organization of lithic technology, it is necessary to analyze the artifacts in a contextual perspective using a distributional approach (Cahen et al., 1979; Boëda et al., 1990; Leesch, 1997; van Gijn, 2003).

\section{Methodological framework}

This methodology demands the articulation of the analytical procedures. An integrative classification of the assemblages is made, taking into consideration morphological, technical and functional features. In the first stage, a typological classification and the techno-morphological description of all the cores, debitage and formal (retouched) tools of the assemblages are performed. Criteria specifically developed for Patagonia are employed (Cardich and Flegenheimer, 1978; Aschero, 1983), complemented by international bibliography (Tixier et al., 1980; Andrefsky, 2005, among others). Afterwards, the analysis of the technomorphological variability of the assemblage is performed through two different approaches. First, the variability of each kind of attribute (i.e. platforms) within the assemblage is evaluated. Second, the technomorphological characteristics of the remains produced during each manufacture stage (i.e. decortication) are analyzed. This approach enables the identification of differences and similarities in tool production strategies (Boëda et al., 1990; Geneste, 1991; Frank, 2011; Cueto and Castro, 2012).

This characterization is designed for the development of an observation strategy which is oriented towards the subsequent functional analysis. The applied methodology is based in Semenov's traceological method (1964) which is the one most commonly employed for the identification of the uses given to lithic tools (Hayden, 1979; Keeley, 1980; Anderson-Gerfaud, 1981; Vaughan, 1981; Mansur-Franchomme, 1983; Plisson, 1985; van Gijn, 2003). Initially, experiments are performed, based on hypotheses formulated regarding the use of tools. Models built with ethnographic and ethnoarchaeological data are taken into account, as they show the dynamics of social conducts in analog situations (Vila, 2006). This experience is then extrapolated during the functional analysis of the archaeological assemblages. From each lithic assemblage, functional analysis is performed on a sample of formal tools and flakes. A stratified sampling is developed, which takes into consideration their size (length and/or width should be greater to $20 \mathrm{~mm}$ ), the kind of raw material, the horizontal distribution of the pieces within the site and, in flakes, the presence of at least one potentially functional edge (sensu Paunero and Castro, 2001). Potentially used flakes without retouch refer to debitage with an adequate size for holding (length or width should be greater than $20 \mathrm{~mm}$ ), and have edges which are at least $20 \mathrm{~mm}$ long. These edges should be straight or convex and have an angle of less than $70^{\circ}$. Prior to functional analysis, it is hypothesized that these potentially used flakes were used to cut. However, the identification of the actual tasks that were performed with these tools is made once the microscopic functional analysis is complete. The results from functional analyses are then interpreted together with the technomorphological characteristics of the artifacts and enable, in some cases, the redefinition of the tool categories used in the studies (Castro, 1994; Briz, 2006-2007).

Studies regarding raw material distribution are also implemented. The formations in which potential lithic sources could be located are identified on geological maps. Afterwards, field surveys are performed in order to locate these sources. Comparisons are made between the raw materials from the sources and those found at the archaeological sites, according to their lithology and quality. The analysis of petrographic thin sections from archaeological remains and raw material from potential sources was performed by various researchers for the study area (Cattáneo, 2002; Hermo, 2008a; Skarbun and Páez, 2012). These studies have been useful for a better identification of the types of rocks. However, the authors 
agree that it is problematic to establish a direct link between archaeological remains and possible provenience sources based in their petrographic determination (Hermo, 2008a; Skarbun and Páez, 2012). This is due to the fact that raw materials with the same lithology are frequent along the Deseado Massif, in an area of more than $90.000 \mathrm{~km}^{2}$. Macroscopic approaches share this limitation. Hence, it is necessary to complement this methodology with the technomorphological study of artifacts from the quarries. It is also useful to analyze the landscape in which the sources are located, taking into consideration their accessibility and visibility (MansurFranchomme, 1983; Frank et al., 2007, 2013; Hermo, 2008a, 2015).

The final step consists of the development of intrasite distributional studies. Maps and density models are created, using different variables such as size, raw material, lithic type and usewear (Cahen et al., 1979; Paunero and Castro, 2001).

Alone, each method provides valuable information. However, superficial archaeological remains). The volcanic activity that this area experienced during the Jurassic has provided excellent raw material for knapping, there are abundant sources of flint, chalcedony, silicified wood and tuffs which crop up in the Chon Aike and La Matilde Formations (Panza, 1994; Skarbun, 2011).

The analysis of the lithic assemblages of three sites from the Central Plateau is presented here. Two of the assemblages belong to Late Pleistocene sites and the other one to a Middle Holocene context (Fig. 1, Table 1). As there are differences regarding the questions and goals that guide the research for each chronological period, and as the excavation of each site has been done in different times in the last thirty years, the reader will notice that each case presents differences in the way the methodology was implemented and in the degree of development of the studies.

Table 1

Dates and characteristics of the sites.

\begin{tabular}{|c|c|c|c|c|}
\hline Site & Unit & ${ }^{14} \mathrm{C}$ Dates & Functionality & References \\
\hline Los Toldos 13 & 9 and 10 & ca. 5500 years BP & $\begin{array}{l}\text { Site of multiple activities; scraping hide, } \\
\text { bone and wood; bone cutting }\end{array}$ & Castro (1994) \\
\hline Casa del Minero 1 & 4 & $\begin{array}{l}10,967 \pm 55 \mathrm{BP} \\
(\mathrm{AA}-37208) \\
10,999 \pm 55 \mathrm{BP} \\
(\mathrm{AA} \mathrm{37207)}\end{array}$ & $\begin{array}{l}\text { Primary and Secondary processing. } \\
\text { Reflaking and retouching }\end{array}$ & $\begin{array}{l}\text { Paunero et al. (2007b), Frank (2011), } \\
\text { Cueto and Castro (2012) and Cueto et al. (2012) }\end{array}$ \\
\hline Cerro Tres Tetas 1 & 5 & $\begin{array}{l}10,260 \pm 110 \mathrm{BP} \\
(\mathrm{LP}-800) \\
10,850 \pm 150 \mathrm{BP} \\
(\mathrm{LP}-781) \\
10,853 \pm 70 \mathrm{~B} \mathrm{P} \\
(\mathrm{AA}-39366) \\
10,915 \pm 65 \mathrm{BP} \\
(\mathrm{OxA}-9244) \\
11,015 \pm 66 \mathrm{BP} \\
(\mathrm{AA}-39368) \\
11,100 \pm 150 \mathrm{BP} \\
(\mathrm{AA}-22233) \\
11,145 \pm 60 \mathrm{BP} \\
(\mathrm{OxA}-10745) \\
11,560 \pm 140 \mathrm{BP} \\
(\mathrm{LP}-525)\end{array}$ & Secondary processing. Hide working & $\begin{array}{l}\text { Paunero and Castro (2001), } \\
\text { Paunero (2009a) and Frank (2011) }\end{array}$ \\
\hline
\end{tabular}

when they become an articulated working corpus, richer interpretations can be achieved. There is a long trajectory of investigations which have developed functional analysis with an integrative approach to lithic artifacts (Cahen et al., 1979; Roebroeks et al., 1997; Terradas and Gibaja, 2001; van Gijn, 2003; Banks, 2004). The articulation of the information obtained through multiple methods allows the formulation of relationships between functional, technological and spatial data, which are helpful in interpreting the socio-economic organization of hunter-gatherer societies. The integration of this approach can be achieved only through long-term team work. The knowledge obtained in each stage creates new perspectives and encourages the application of new methods. Therefore, it is important to go through the employed criteria as often as possible and to reformulate them when necessary.

\section{Lithic analyses in the Central Plateau of Santa Cruz}

The Central Plateau of Santa Cruz is one of the extensive plateaus which are characteristic of Patagonia and are dominated by a steppe environment. Its altitude varies from 100 to 500 masl. The plateau is interrupted by isolated hills, ravines, valleys and endorheic lake basins. Notable in the area are caves or shelters in ignimbrites; many of them show evidence of past human presence in the area (rock art,

\subsection{The colonizing contexts}

Unit 5 from Cerro Tres Tetas 1 (C3T1) and unit 4 from Casa del Minero 1 (CDM1) are examples of initial occupations of the Patagonia region, which took place ca. 11,000 years ${ }^{14} \mathrm{C}$ BP (Table 1 ), during the Antarctic Cold Reversal (Paunero, 2009b). The first colonization of Patagonia has been described as a very slow process, with short-term occupations by small groups (Miotti and Salemme, 2004; Paunero, 2009b). According to Miotti and Salemme (2004), the mobility of the populations in the Central Plateau was restricted to the areas were the majority of the resources could be found. A generalized subsistence strategy was developed; the guanaco was the main prey but other species were also hunted, many of which are now extinct. In all the sites from this time period a low density of lithic remains has been recovered.

Until the 1980's the culture-history school of thought dominated the discussions regarding the lithic technology of the first societies. Among the most important discussions highlights the one referring the technical capabilities of these early inhabitants. Based on the remains recovered from the level 11 of the site Cueva 3 from Los Toldos, Cardich and Flegenheimer (1978) state that these groups lacked bifacial technology. Bifacial artifacts would only appear later on with the emergence of the cultures known as Toldense and Fell 1 (Skarbun, 2011). It is important to highlight that the 


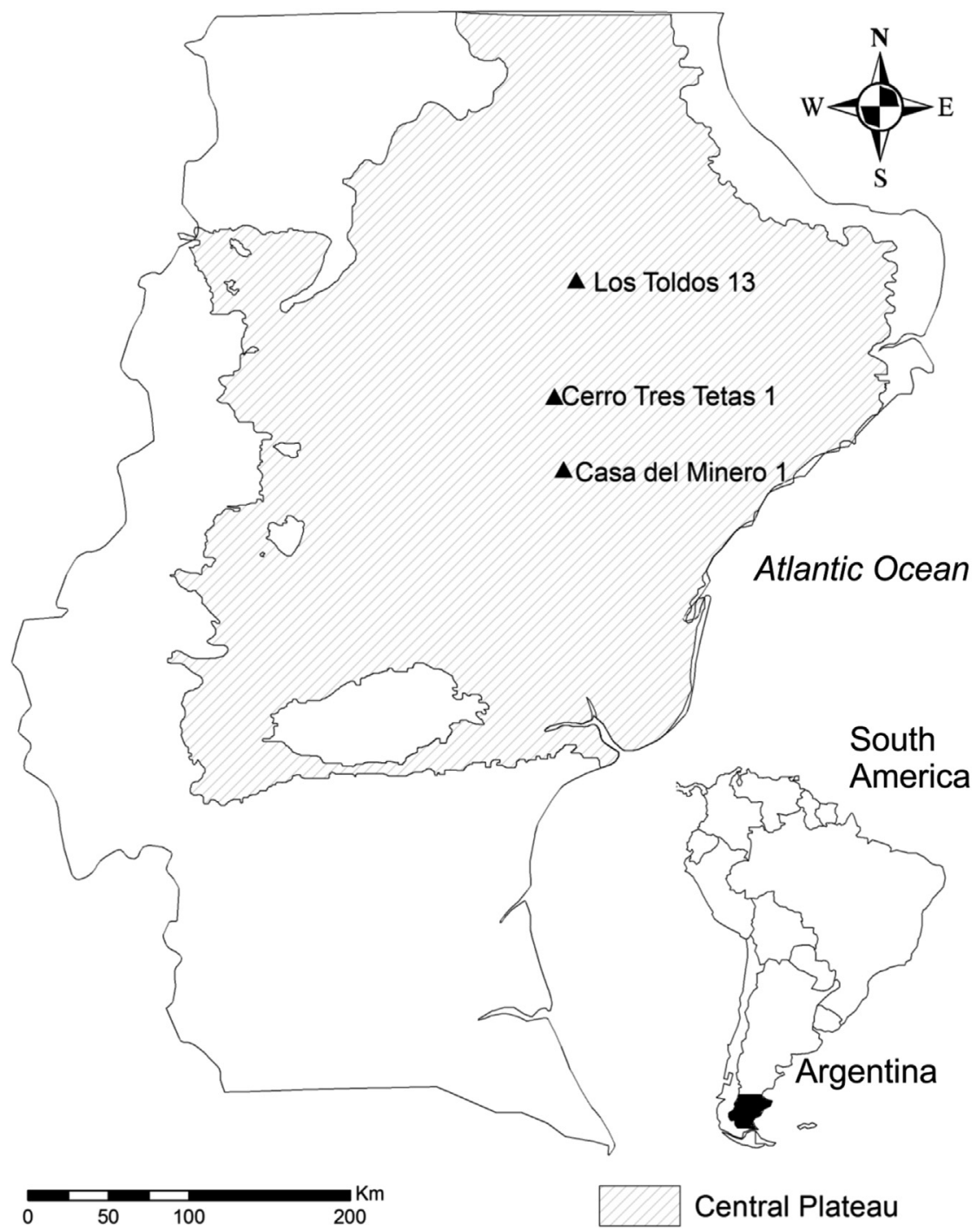

Fig. 1. Location of the sites in the Central Plateau of Santa Cruz, Argentina.

level 11 has only one radiocarbon date. The date, of 12,600 years ${ }^{14} \mathrm{C}$ $\mathrm{BP}$, has been discussed by the archaeological community (Borrero, 1999; Miotti and Salemme, 2003; Paunero, 2009b).

Since the 1990's, and with the excavation and dating of the site Alero El Puesto 1 (also known as Piedra Museo), the presence of bifacial technology within the first occupations of the area is confirmed. Particularly, this technique was used in the production of the fishtail projectile points. From that moment, the analyses focus on the organization of lithic production. In this context, Borrero and Franco (1997) suggest a series of expectations for early technology, based on an ecologic and evolutionary model. These expectations include: an abundance of expediently shaped artifacts, adequate for immediate use; lower frequencies of curated artifacts and the presence of debitage associated with the final shaping of transported artifacts. According to these authors, versatility should have been prevalent due to the requirements of transportability of tools in an unfamiliar territory. In this sense, they believe bifacial artifacts are especially suitable for transport when high mobility is required (Borrero and Franco, 1997). However, the functional analysis of the tools was not included as a relevant factor in the formulation of this model.
The sites presented in this article can give new and important information for the discussion of the topics mentioned above. C3T1 is a cave of approximately $120 \mathrm{~m}^{2}$, of which $12.25 \mathrm{~m}^{2}$ were excavated between 1994 and 1995. The cave is located next to a stream and faces west. A secondary lithic source can be found $600 \mathrm{~m}$ away from the site; nodules of flint, chalcedony and silicified wood of excellent to regular quality for knapping can be gathered there. The excavation of the site showed that it had been inhabited in several occasions, ranging from the final Pleistocene to historical times (Paunero, 1993-94). The walls of the cave show many rock paintings, including a final Pleistocene hunting scene (Podestá et al., 2005). The stratigraphy is fairly horizontal and each stratigraphic unit is separated by a clear boundary (Paunero, 2009a). In unit 5, four flat hearths were recorded in the inner part of the cave. Only 106 bone remains were found, belonging mostly to Lama guanicoe. Paunero's study indicated that the intentional fracture of limb bones and the consumption of marrow were not activities commonly performed at the site. Furthermore, few cooking activities took place there (Frank and Paunero, 2009; Paunero, 2009a). Two bone tools were found at the site, an awl and a retouched diaphysis of a tibia from a guanaco. Both were probably used during secondary processing activities on hide (Paunero et al., 2010). 
CDM1 is $68.20 \mathrm{~m}^{2} ; 15.32 \mathrm{~m}^{2}$ were excavated between 2000 and 2004. The cave is located next to a ravine and also faces west. A primary source of red and yellow flint, of very good/excellent quality for knapping, is located $620 \mathrm{~m}$ away from the site (Frank et al., 2007). As with C3T1, CDM1 is a multicomponent site. It has four stratigraphic layers with occupations ranging between the final Pleistocene and the beginnings of the 20th century. These deposits are horizontal. Unit 4 (Table 1) is the final Pleistocene occupation presented in this article. It is separated from unit $3 \mathrm{c}$ (which has a date of AA 45705: $10.250 \pm 110$ years ${ }^{14} \mathrm{C} B$ ) by a clear line of collapse rocks (Paunero et al., 2007b). This means that the archaeological remains of unit 4 were buried shortly after they were discarded. Ten flat, elliptical hearths were recorded in unit 4. In the zooarchaeological assemblage, remains from Lama guanicoe are prevalent and there are also bones from two extinct camelids: Hemiauchenia paradoxa and Lama gracilis. Most of the remains from these species were found surrounding the hearths. Fox and Rheidae (South American Ostrich) remains are also found. In this unit faunal remains show evidence of exploitation and consumption, including processing and cooking activities. Several anthropogenic marks were recorded on the faunal assemblage such as spiral and longitudinal fractures, flake scars, cut marks and thermally altered bones. Furthermore, two awls and a multipurpose tool (an awlretoucher) made on diaphysis of camelids were manufactured and discarded at the site (Paunero et al., 2007b).

A total amount of 510 lithics were excavated in unit 5 from C3T1 (41.63 lithics $/ \mathrm{m}^{2}$ ), while 1240 lithics were recovered from unit 4 of CDM1 (80.94 lithic remains $/ \mathrm{m}^{2}$ ). Technomorphological analysis was performed on all of the artifacts in both assemblages (Table 2). Debitage predominates in the assemblages (92.94\% and $99.11 \%$ respectively, Table 2 ).

Table 2

General structure of the lithic assemblages of the three sites. Both complete and fractured flakes (proximal, medium and distal fragments) were taken into account.

\begin{tabular}{|c|c|c|c|c|c|c|}
\hline \multirow[t]{2}{*}{ Site/Unit } & \multicolumn{2}{|c|}{$\begin{array}{l}\text { Los Toldos } \\
13 / \mathrm{U} 9 \text { and } 10\end{array}$} & \multicolumn{2}{|c|}{$\begin{array}{l}\text { Cerro Tres } \\
\text { Tetas } 1 / \mathrm{U} 5\end{array}$} & \multicolumn{2}{|c|}{$\begin{array}{l}\text { Casa del Minero } \\
1 / \mathrm{U} 4\end{array}$} \\
\hline & $\mathrm{n}$ & $\%$ & $\mathrm{n}$ & $\%$ & $\mathrm{n}$ & $\%$ \\
\hline Cores & 22 & 1.10 & 5 & 0.98 & 0 & 0 \\
\hline Debitage & 1921 & 96.53 & 474 & 92.94 & 1229 & 99.11 \\
\hline Formal tools & 47 & 2.36 & 31 & 6.08 & 11 & 0.89 \\
\hline Total & 1990 & 100 & 510 & 100 & 1240 & 100 \\
\hline
\end{tabular}

At both C3T1 and CDM1, tools were manufactured at the sites with local, good quality raw material. Initial flaking stages were not performed at the sites, as there are few decortication flakes (17.67\% in C3T1 and 3.67\% in CDM1, Fig. 2). This task was probably fulfilled at the quarries nearby (Frank et al., 2007; Frank et al., 2015). At both sites, the final stages of production were performed (69.77\% in C3T1 and $63.43 \%$ in CDM1). Human groups finished the manufacture of tools by retouch or bifacial thinning. Normal and wide flakes were selected as preforms and used for the production of tools which are morpho-functionally adapted to hand prehension (Paunero and Castro, 2001; Cueto et al., 2012). There are very few blades $(2.09 \%$ in C3T1 and 3.25\% in CDM1). Significant amounts of the final trimming debris correspond to bifacial thinning flakes (14.29\% in C3T1 and 10.24\% in CDM1) (Paunero, 2009a; Frank, 2011; Skarbun, 2011). An interesting characteristic from these sites is that many of the lithics have been heat treated. Heat treatment is most commonly found in flakes produced during the final shaping of tools (Fig. 3), especially in retouch and bifacial thinning debris. At CDM1, 70.8\% of the bifacial thinning flakes were heat treated while $33.3 \%$ of bifacial thinning flakes were heat treated at C3T1 (Frank, 2012).

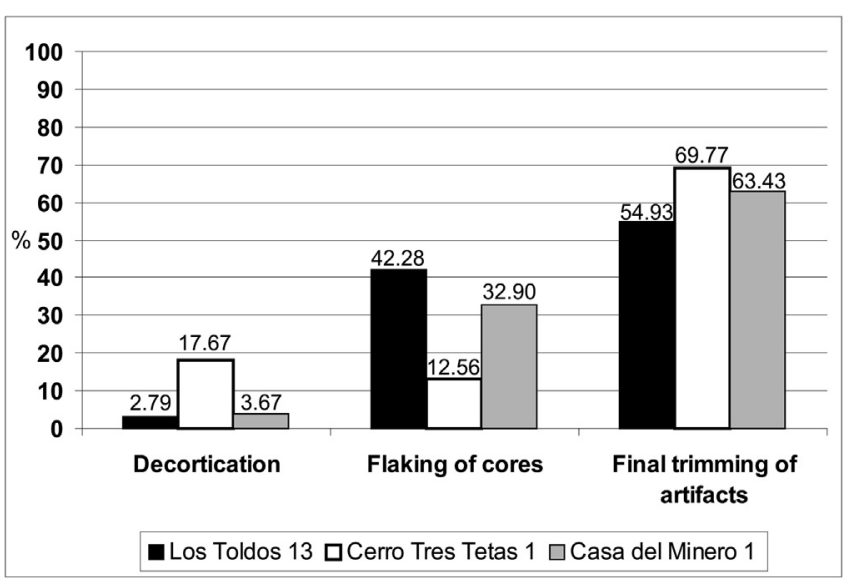

Fig. 2. Flaking stages in debitage.

The majority of the formal tools consisted of retouched flakes (29.03\% at C3T1 and 54.5\% at CDM1). At C3T1, there are also many end-scrapers and side-scrapers (22.58\% each, Table 3 ). These tools were manufactured primarily on immediately available flint from sources located at less than one $\mathrm{km}$ from the sites $(64.52 \%$ at C3T1 and 54.54\% at CDM1). The rest of the tools are all made on materials which are found in a radius of $10 \mathrm{~km}$ from each site. The heat treated tools from C3T1 are bifacial artifacts (two preforms and a biface, all broken) while at CDM1 a knife and a retouched flake were treated. The retouched flake and the heat treated bifacial thinning flakes were removed from the same blank. There is only one bifacial preform in this unit, which doesn't show heat treatment, and no bifacial finished tools.

Table 3

Formal tools from each site.

\begin{tabular}{|c|c|c|c|c|c|c|}
\hline \multirow[t]{2}{*}{ Site } & \multicolumn{2}{|c|}{ Los Toldos 13} & \multicolumn{2}{|c|}{ Cerro Tres Tetas 1} & \multicolumn{2}{|c|}{ Casa del Minero 1} \\
\hline & $\mathrm{n}$ & $\%$ & $\mathrm{n}$ & $\%$ & $\mathrm{n}$ & $\%$ \\
\hline Retouched flakes & 0 & 0 & 9 & 29.03 & 6 & 54.5 \\
\hline Side-scrapers & 1 & 2.13 & 7 & 22.58 & 1 & 9.10 \\
\hline End-scrapers & 31 & 65.96 & 7 & 22.58 & 1 & 9.10 \\
\hline Knives & 4 & 8.51 & 3 & 9.68 & 1 & 9.10 \\
\hline Bifacial tools & 0 & 0 & 3 & 9.68 & 1 & 9.10 \\
\hline Ground stones & 5 & 10.64 & 0 & 0 & 0 & 0 \\
\hline Other & 6 & 12.76 & 2 & 6.45 & 1 & 9.10 \\
\hline Total & 47 & 100 & 31 & 100 & 11 & 100 \\
\hline
\end{tabular}

When considering functional and contextual information, the assemblages have differences and similarities. Our investigations showed that CDM1 (Fig. 4A) was a site where primary and secondary processing of animals was performed, as well as the final production of bone tools and leather goods (Paunero et al., 2007b; Cueto et al., 2012).

At CDM1, 11 formal tools (100\%) and 33 flakes with potentially functional edges (47.82\%) were analyzed for use-wear traces. Seven of the tools (63.63\%, eight retouched edges) had evidence of use. The remaining four tools (36.37\%) and all the flakes did not have use traces. The edges of the formal tools were used for only one movement and on one contact material. One retouched flake was used to scrape hide with two edges. The working angle was lower than $45^{\circ}$, the ventral face of the flake was touching the hide. Two other retouched flakes scraped hard substances (one of them probably worked bone or wood). A fourth flake with unifacial retouch was used to cut bone; the working angle was $90^{\circ}$ and both faces of the flake contacted the bone. The scraper was used to 


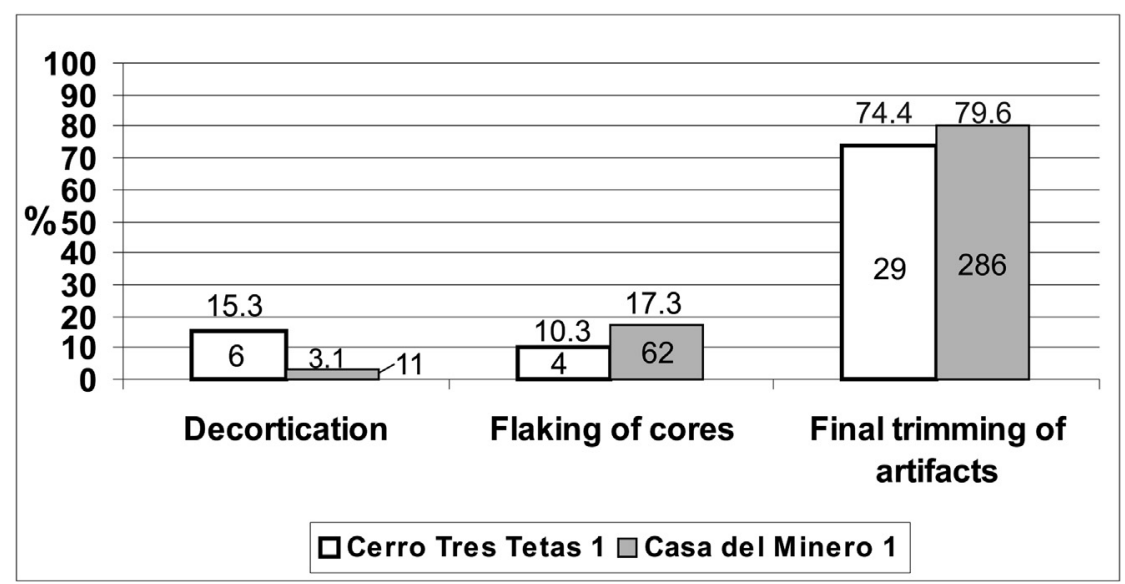

Fig. 3. Heat treated flakes from C3T1 and CDM1. 1: Decortication; 2. Flaking of cores; 3. Final trimming of artifacts.
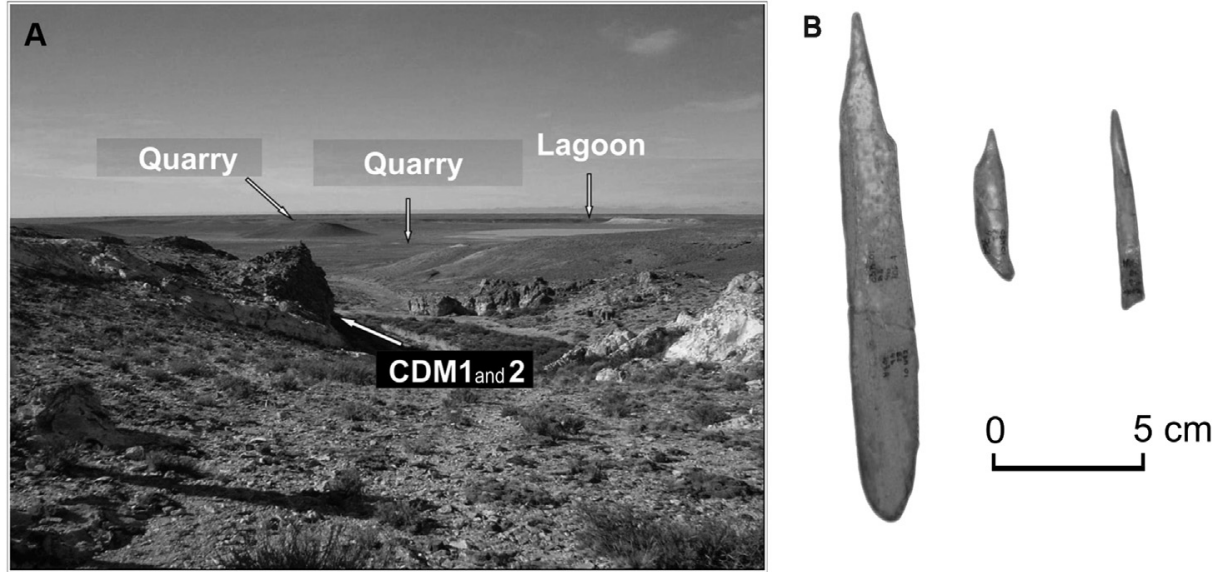

Fig. 4. A) Location of site Casa del Minero 1 and two quarries nearby; B) Bone artifacts: awl-retoucher and two awls.

process hide with transversal movements. The end-scraper edge from a tool with two retouched edges (end-scraper/side-scraper) was used for the same activity. The working angle was larger than $70^{\circ}$ with perpendicular movements to the edge; the ventral side was facing the hide. A knife was used to process a soft tissue from an animal, with longitudinal movements (Fig. 5). This group of tools

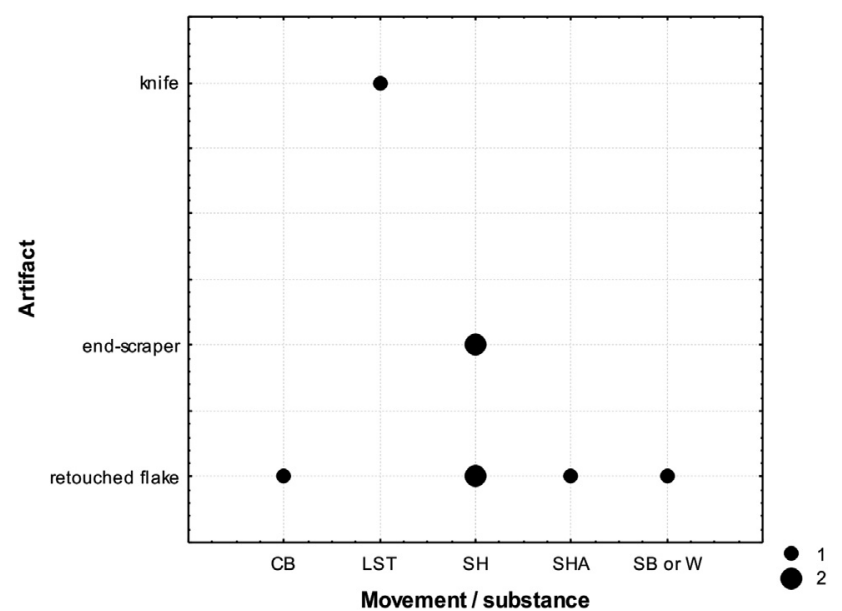

Fig. 5. Use-wear identified for each kind of artifact. CDM1. CB: cut bone; LST: longitudinal soft tissue; SH: scrape hide; SHA: scrape hard; SB or W: scrape bone or wood. was manufactured for hide processing (in order to take away the remaining organic materials or to tan the hide), and soft tissue and bone cutting (possibly during disarticulation tasks or to separate soft tissue) (Fig. 6-D) (Cueto et al., 2012; Cueto, 2014). Cutting tasks may also be involved in secondary processing activities for the production of the bone tools which were manufactured at the site (Fig. 4B). It is very likely that bone retouchers were used during the final trimming of lithic artifacts. Thus, some of the lithic tools found at the site were likely used to manufacture bone artifacts which were then used to retouch other stone tools. No traces of hafting were identified during the functional analysis of this assemblage.

Distributional analyses enabled the identification of stone debris clusters near specific hearths, which relate to reduction events from different cores, specially the final stages of manufacture on determinate raw materials (Skarbun and Frank, 2011). At the same time, tools with use-wear were located next to fire structures. Most of them were used in the processing of chamelids, among the prey hunted in the area (Cueto, 2014).

At C3T1, the functional analysis was performed on 22 formal tools (70.97\%), three cores and $54.24 \%$ of the debitage with potentially functional edges ( 32 flakes and two blades). Use-wear was identified on 17 (77.27\%) tools and on three (8.82\%) flakes. Cores didn't show any evidence of use. As in the case of CDM1, functional analysis showed that the majority of the tools were used for only one movement and with just one contact material. Only two were used for multiple functions (one end-scraper which scraped bone and hide and one side-scraper which scraped and cut hide). $71.4 \%$ of 


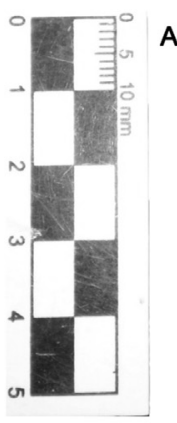

A
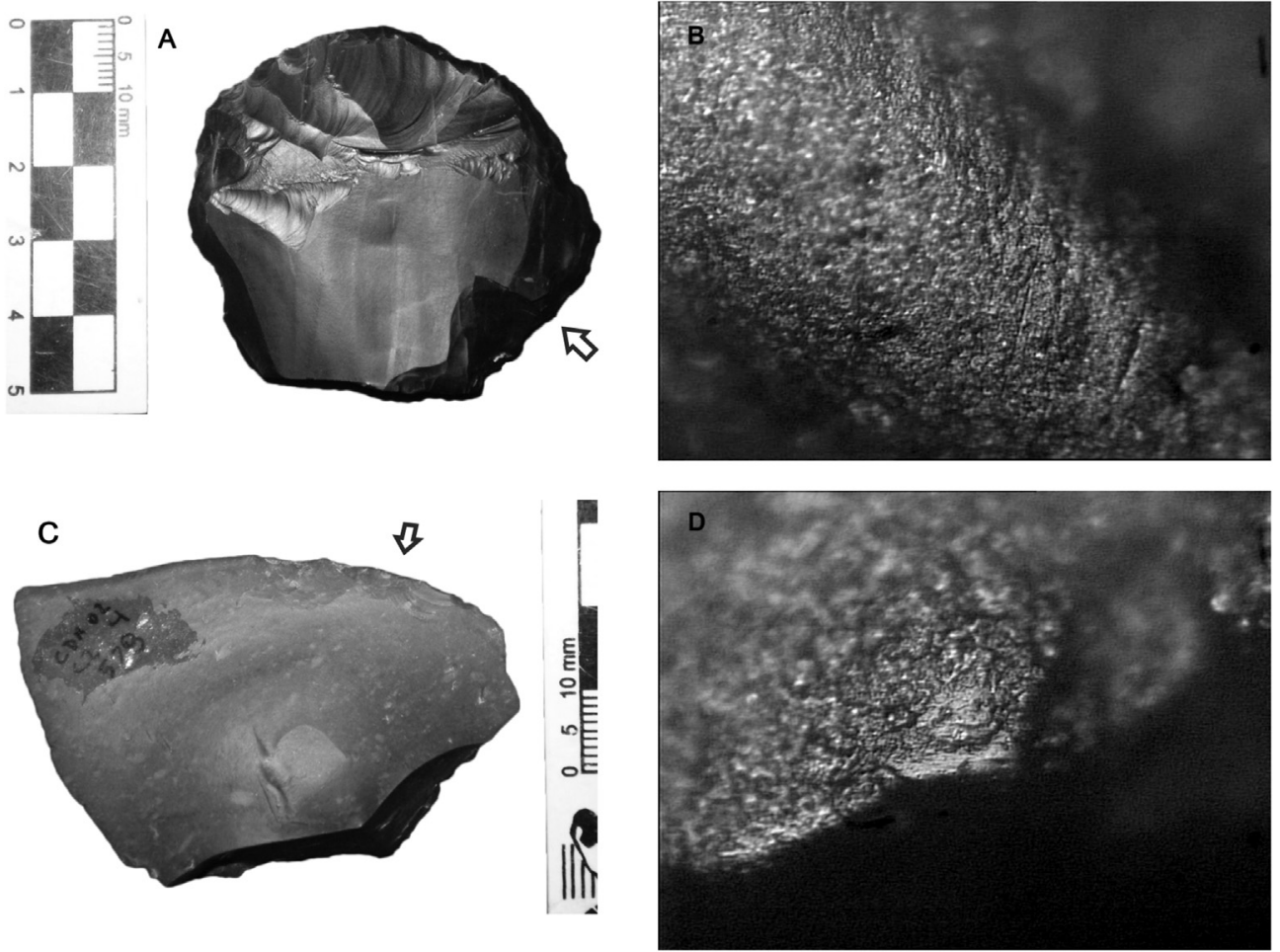

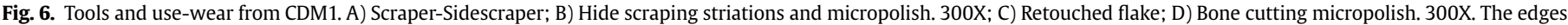
with traces are signaled by arrows.

the analyzed end-scrapers showed use-wear. They were used in transversal movements. $80 \%$ of the analyzed edges from endscrapers were used to process hide, one of them also worked on bone. Typologically knives, side-scrapers and retouched flakes were classified separately. However, functional analysis showed their edges were used in longitudinal motions (66.67\%), for tasks related to the processing of hide and secondly of bone. An unretouched blade was used to cut hide, while two flakes had undetermined use-wear (Fig. 7).

When articulating functional analysis results with intrasite distribution analyses, it became evident that most activities involving hide working were performed in the inner space of

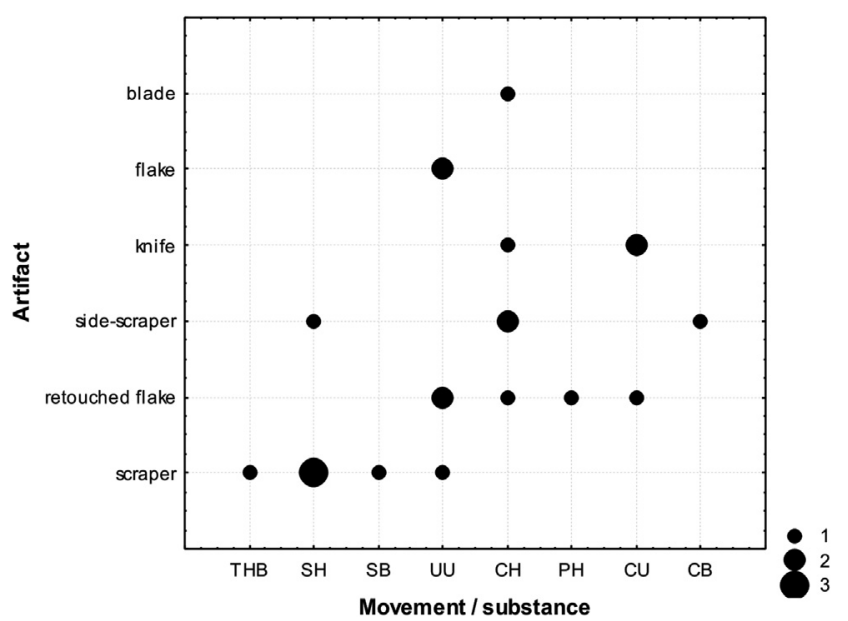

Fig. 7. Use-wear identified for each kind of artifact. C3T1. THB: transversal hide, bone; SH: scrape hide; SB: scrape bone; UU: undetermined/undetermined; $\mathrm{CH}$ : cut hide; $\mathrm{PH}$ : perforate hide; $\mathrm{CU}$ : cut undetermined; $\mathrm{CB}$ : cut bone. the cave. Two activity areas were recognized: one where hide was scraped and another one where hide and bone were cut (Fig. 8A). Furthermore, the two bone tools found were probably used for hide processing (Paunero et al., 2010). Therefore, both lithic and bone tools indicate that hide working activities were performed at the cave (Fig. 8B). These activity areas were located around combustion structures. The same happens with knapping activities, as the debitage is usually clustered around the hearths, which were also used to heat treat blanks (Frank, 2012).

In both sites, a diversity of strategies in the production of artifacts can be identified. These strategies are related to the quality and abundance of raw materials, the distance to the sources, and the tasks in which the lithic tools were going to be used (e.g. butchering, leather tanning).

The initial stages of tool production were performed outside the sites, in the quarries nearby and most of the tools demanded low investment of energy. Both decisions are related to the availability of excellent quality flint in the surroundings. Nevertheless, flakes with unretouched edges were usually not used. Therefore, some decisions regarding production were not only related to raw material availability but also with functional needs or preferences. In this sense, the technological assemblages were functionally designed for different tasks (Skarbun, 2011; Cueto and Castro, 2012; Cueto et al., 2014). The analysis shows that the toolkits were designed for specific functions, as the majority of the tools were only used for just one kind of activity on one kind of substance. This fact contradicts the model of Borrero and Franco (1997) with regards to the versatility of the assemblages. In addition, the characteristics of the assemblages show technological relationships with other early sites of the region and the morphologies for the tools are those expected for early contexts. The size of the tools is optimal for hand prehension and for the application of pressure on different substances. This fits with the results of functional analysis 


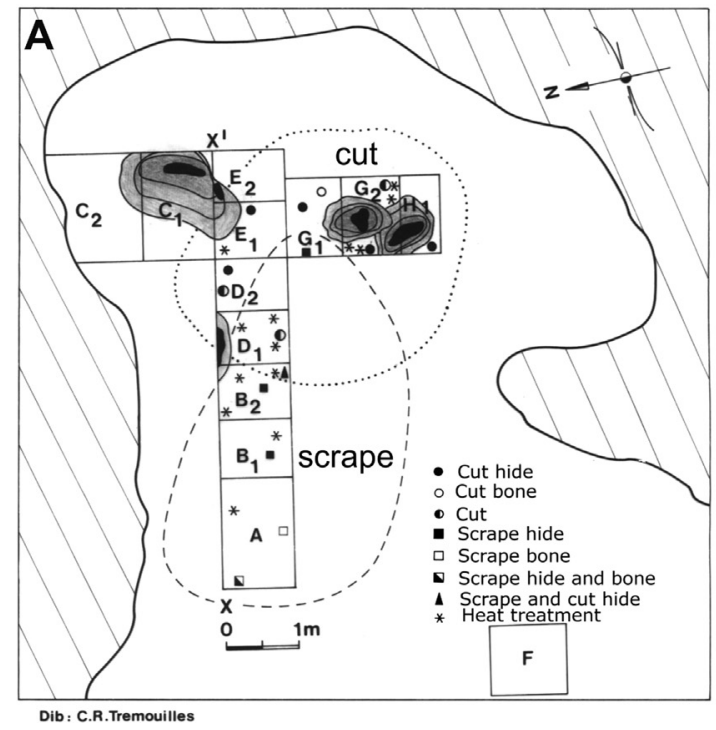

B

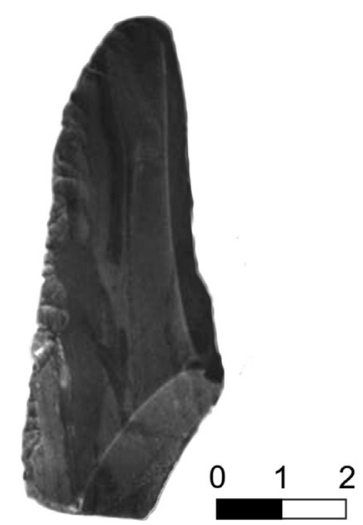

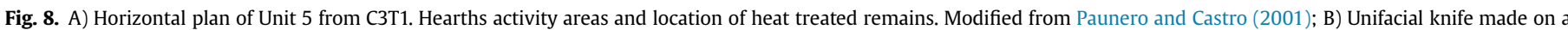
long flake. It was used to cut hide.

that indicated these tools were used unhafted (Paunero and Castro, 2001; Cueto et al., 2012).

These groups had a deep technological knowledge and were able to solve immediate needs and simple tasks, as well as more complex planned labors. These technical capacities were articulated in a group of expeditive and curated strategies according to the needs and requirements of the social and environmental world. Two main production avenues were identified; one with simple unifacial expedient artifacts (retouched flakes, end-scrapers, sidescrapers and knives) which were made at the sites, used for daily tasks and discarded there. Another more complex strategy with high energy investment, involved heat treated bifacial artifacts, made at the sites but used and discarded outside them. This probably implies a curated strategy which, we believe, was aimed at the production of projectile points, when taking into consideration background information regarding this kind of artifact in the region (Nami, 1992; Hermo, 2008b). That is to say, the production of bifacial tools does not seem to be oriented toward the manufacture of versatile designs (sensu Borrero and Franco, 1997).

Likewise, the study of raw material characteristics, reduction methods, artifacts function and distribution has shown that hearths structured the internal space at these caves. There, multiple activities were performed: the final shaping of tools (including the heat treatment of lithic blanks), their use in the processing of prey and the cooking of food (Paunero and Castro, 2001; Frank, 2011; Skarbun and Frank, 2011; Cueto, 2014). That is to say, fire seems to have played an important role in the organization of productive processes, both as a means to improve the quality of raw material and as a focus around which work was performed.

Hence, these groups had a controlled management of fire, which was integrated to an intrasite system of specific working areas, high efficiency in the production techniques of a toolkit which was designed for specific purposes related to the processing of faunal products (Paunero, 2009a; Frank, 2011).

\subsection{The Middle Holocene context}

The Middle Holocene in the Central Plateau was characterized by an arid climate (Mancini et al., 2005). It has been proposed that during this time period local hunter-gatherers had a reduced residential mobility. It has also been claimed that a consolidation of regional social networks occurred, facilitating the long-distance movement of goods and information (Miotti and Salemme, 2004). Subsistence was based on hunting Lama guanicoe (guanaco), indicating a specialized strategy. All the Middle Holocene sites in the region are located in caves or rock shelters, and they all have a high artifact density when compared to the colonizing contexts.

The lithic technology of this time period is commonly referred as the Casapedrense Industry (Menghin, 1952). Its main characteristics are the predominance of blades, the absence of bifacial projectile points and the presence of bolas (Menghin, 1952; Crivelli Montero, 1980; Durán, 1986-1987; Cardich and Paunero, 1991-92; Cardich et al., 1993-1994; Castro, 1994; Paunero et al., 2007a; Hermo and Magnin, 2012). The discussions regarding this technological complex have been traditionally presented from a normative point of view (Menghin, 1952; Cardich et al., 1973; Gradin, 1980; Orquera, 1984-85; Aschero, 1987). There was an emphasis on the determination of typologies and certain types of tools were linked to specific cultures. The variability of the archaeological assemblages of this time period was usually unnoticed. Besides, the technological capabilities of the Middle Holocene societies were assessed based on the characteristics of the archaeological remains. In this sense, due to its technomorphological traits, some authors have interpreted that the Casapedrense was a "poor" lithic industry, when comparing this technological complex to previous local developments with fine bifacial tools (Menghin, 1952). However, current analyses show that bifacial artifacts were in fact produced during this time period (although in a much less intensive way), but were discarded outside of caves, making their recovery less likely (Skarbun, 2011; Hermo and Magnin, 2012).

Since the mid 1980's, the technological observations of the Middle Holocene lithic assemblages are focused on understanding the production process of blades and tools (Durán, 1986-1987; Cardich and Paunero, 1991-92). By the end of the 1990's, based on systemic economic studies, regional stone tool research starts to incorporate ideas and models of authors such as Nelson (1991). Hence, the strategies of tool production are more thoroughly discussed (Cueto et al., 2014). In this sense, Hermo (2008a) states that Middle Holocene blade technology was not a consequence to a 
need of raw material maximization, as raw materials are abundant in the region. On the contrary, he believes blades are versatile, flexible, transportable, maintainable and reliable artifacts. The observations of this author are made based on technomorphological and raw material studies (Hermo, 2008a). However, the functionality of these artifacts is not taken into consideration.

In this context, we present here the analyses performed on the First Cultural Level from site Cueva 13 from Los Toldos Locality (Fig. 9A). Cueva 13 is a large west-facing rock shelter of approximately $400 \mathrm{~m}^{2}$, located near a stream. The walls of the cave show hand stencils and anthropomorphic paintings. Excavation of Cueva 13 took place in 1985 . Seven $\mathrm{m}^{2}$ were excavated and the stratigraphy consisted of 11 layers. Middle and late Holocene occupations were identified (Castro, 1994).

The Middle Holocene occupation was named the First Cultural Level (units 9 and 10). Three hearths were recorded in this level; one of them is a cuvette (sensu Leroi-Gourhan, 1979) which is covered with stones. The remaining two are flat hearths. Within the abundant zooarchaeological assemblage, Lama guanicoe remains are prevalent, especially those from limbs (Castro, 1994; Miotti, 1998).

A total amount of 1990 lithic artifacts were recovered from the excavation of the First Cultural Level, with a density of 284.29 lithics per $\mathrm{m}^{2}$. Technomorphological analysis was conducted on the entire assemblage (Table 2). There is a clear predominance of debitage in the lithic assemblage (96.53\%), while formal tools and cores are very scarce (Table 2). There is evidence that the knapping of cores and the final trimming of artifacts (sensu Skarbun et al,
2007) were performed at the site. There are few decortication flakes $(2.79 \%)$, indicating that the cores were brought to the cave without cortex and that this stage of the reduction sequence was done somewhere else, probably the nearby quarries (Fig. 2) (Castro, 1994). The site has a higher percentage of blades (11\%) in contrast to former occupations in the region.

The typological structure of the formal tools is constituted mostly by end-scrapers (65.96\%, Table 3, Fig. 9B and C). There are few knives and sidescrapers (Fig. 9B), while bifacial artifacts are absent (Castro, 1994). The tools were manufactured on silicified tuff (87.23\%), an immediately available, cryptocrystalline raw material of good quality for knapping. This tuff is commonly found locally, both as nodules in primary outcrops or as cobblestones in nearby lagoons and gorges. The remaining tools were made on pumiceous rocks (8.51\%), rhyolite $(2.13 \%)$ and obsidian (2.13\%). Pumiceous rocks are also available at the locality. The nearest source of the obsidian is located $200 \mathrm{~km}$ away from the site (Pampa del Asador; Espinosa and Goñi, 1999); the source of the rhyolite is up to date unknown.

Functional analysis of 34 formal tools $(72.34 \%)$ was performed. Six broken tools and two end-scrapers were not analyzed due to patination and the presence of soil sheen. Furthermore, five ground stones were also not analyzed. These ground stone artifacts are bolas, which are known to have been used as range weapons to tackle animals during hunting. This kind of use does not leave any micropolish in the tool. One hundred and ten flakes and blades were also analyzed (consisting of $16.49 \%$ of the debitage with potentially functional edges) (Castro, 1994). Results showed that 30
A

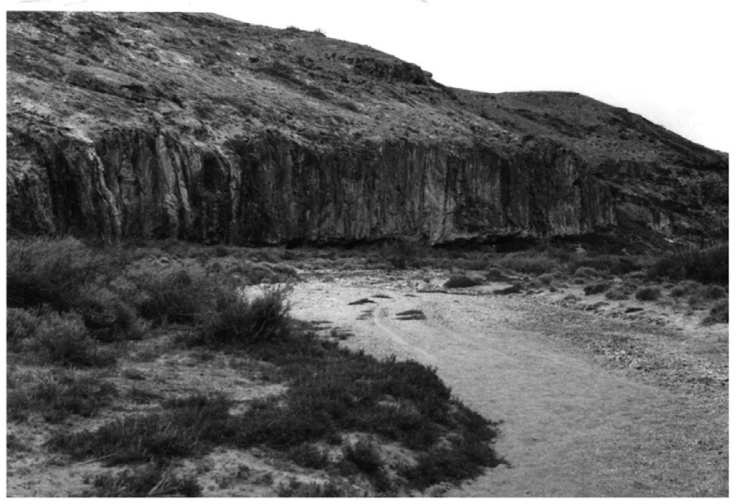

B

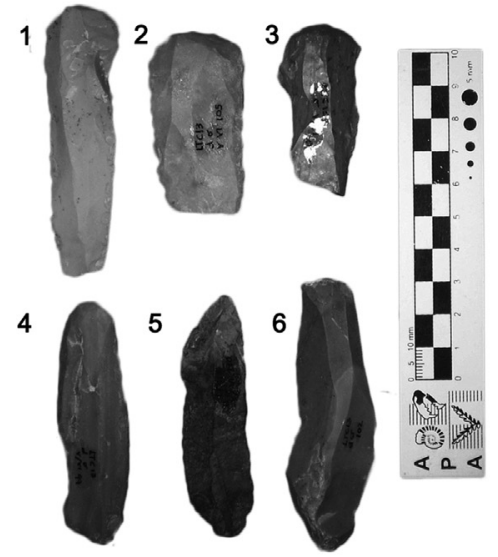

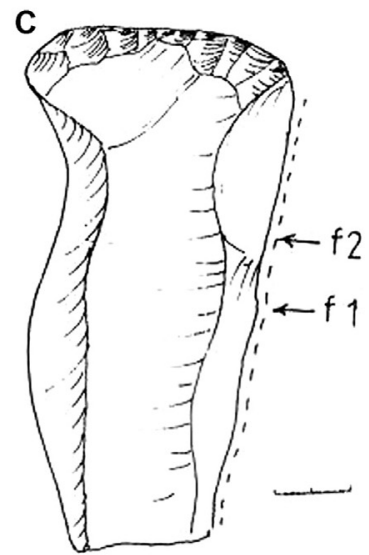

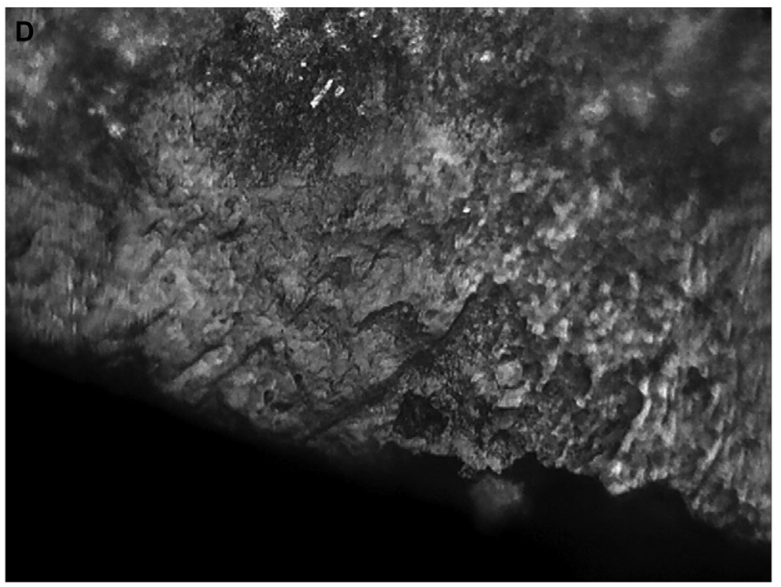

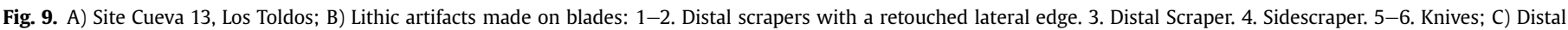
scraper. Lateral right edge was used; D) Microphotographs of bone scraping polish. 280X. 


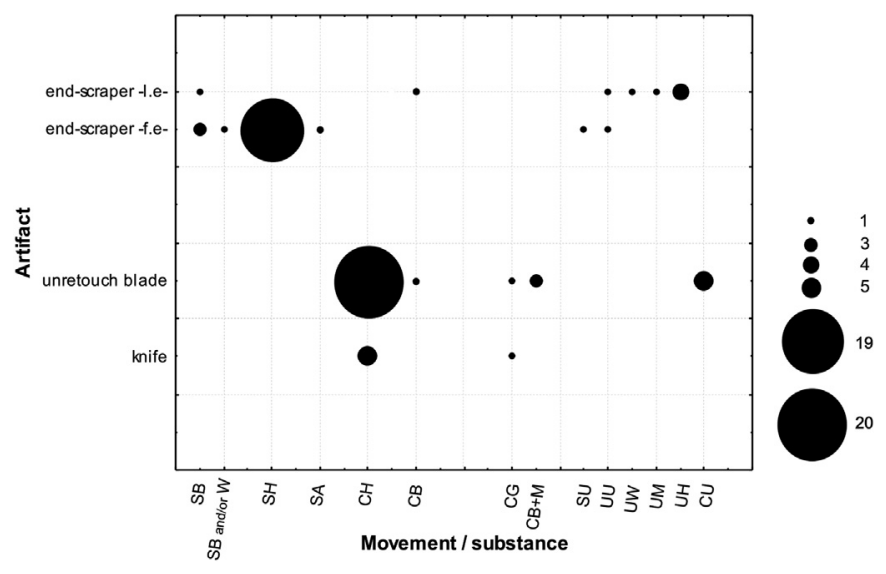

Fig. 10. Use-wear identified for each kind of artifact. LT3. l.e: lateral edge; f.e: frontal edge; SB: scrape bone; SB and/or W: scrape bone and/or wood; SH: scrape hide; SA: scrape antler; $\mathrm{CH}$ : cut hide; $\mathrm{CB}$ : cut bone; $\mathrm{CG}$ : cut gramineae $\mathrm{CB}+\mathrm{M}$ : cut bone + meat; SU: scrape undetermined; UU: undetermined/undetermined; UW: undetermined wood; UM: undetermined meat; UH: undetermined hide; CU: cut undetermined.

(88.24\%) of the formal tools were used. Of these tools, 43 edges show use-wear or hafting traces. Only three end-scrapers and one side-scraper did not show signs of use or they couldn't be identified because of natural alterations. Twenty-two unretouched blades (22.68\%) also had evidence of use and 30 of their edges show usewear (Fig. 10). This fact contrasts with the colonizing contexts in which natural edges of debitage were hardly ever used. On the contrary, the 13 analyzed flakes (100\%) did not show any sign of utilization.

Nineteen of the tools that were classified typologically as endscrapers were used to scrape hide (out of 26 with use-wear). The working angle was usually larger than $45^{\circ}$ with perpendicular movements to the frontal edge, which was the active one. Microtraces of bone (Fig. $9 \mathrm{C}$ and D), wood and antler scraping were also identified (Castro, 1994) (Fig. 10). When taking into account the type of blank used to make these end-scrapers, in conjunction with the shape and microwear of the lateral edges, technological differences became evident. $74.2 \%(n=23)$ of the scrapers were made on blades, the remaining $25.8 \%(\mathrm{n}=8)$ being manufactured on flakes. $87.5 \%(n=7)$ of the end-scrapers made on flakes have at least one retouched lateral edge, which nevertheless showed no signs of being used or hafted. On the contrary, $82.6 \%(n=19)$ of those fabricated on blades have unretouched lateral edges. These lateral edges were used to work on bone, hide, meat and wood (Fig. 10). Additionally, on four end-scrapers made on blades, the lateral edges and/or the face of the tools showed evidence of hafting. Three of the hafted end-scrapers were used to scrape bone. More strength is needed to modify bone in comparison to other softer materials; hafting would be a successful way to solve this problem (Castro, 1994; Rots, 2010).

Therefore, functional analysis has enabled the identification of three tool categories: hafted and unhafted scrapers and artifacts with multiple functions (Fig. 11). Regarding end-scrapers made on flakes, the retouching of lateral edges can be understood as a way to regularize them, in order to give the flake a rectangular, blade like shape, which could be considered a culturally defined style. That is to say, the blades were the preferred morphologies and technical procedures were implemented in order to obtain them (Castro, 1994).

Retouched artifacts classified typologically as knives (Fig. 9B) were used to cut hide ( $75 \%, \mathrm{n}=3)$, but there is one $(25 \%, \mathrm{n}=1)$ which has cut gramineae (grasses). One or two edges were used on each knife. Micropolishes are not intense, showing that tools were discarded once they became damaged or their edges went dull. This may be due to the high efficiency of the natural edges to fulfill the task, as all the unretouched blades were also used as cutting

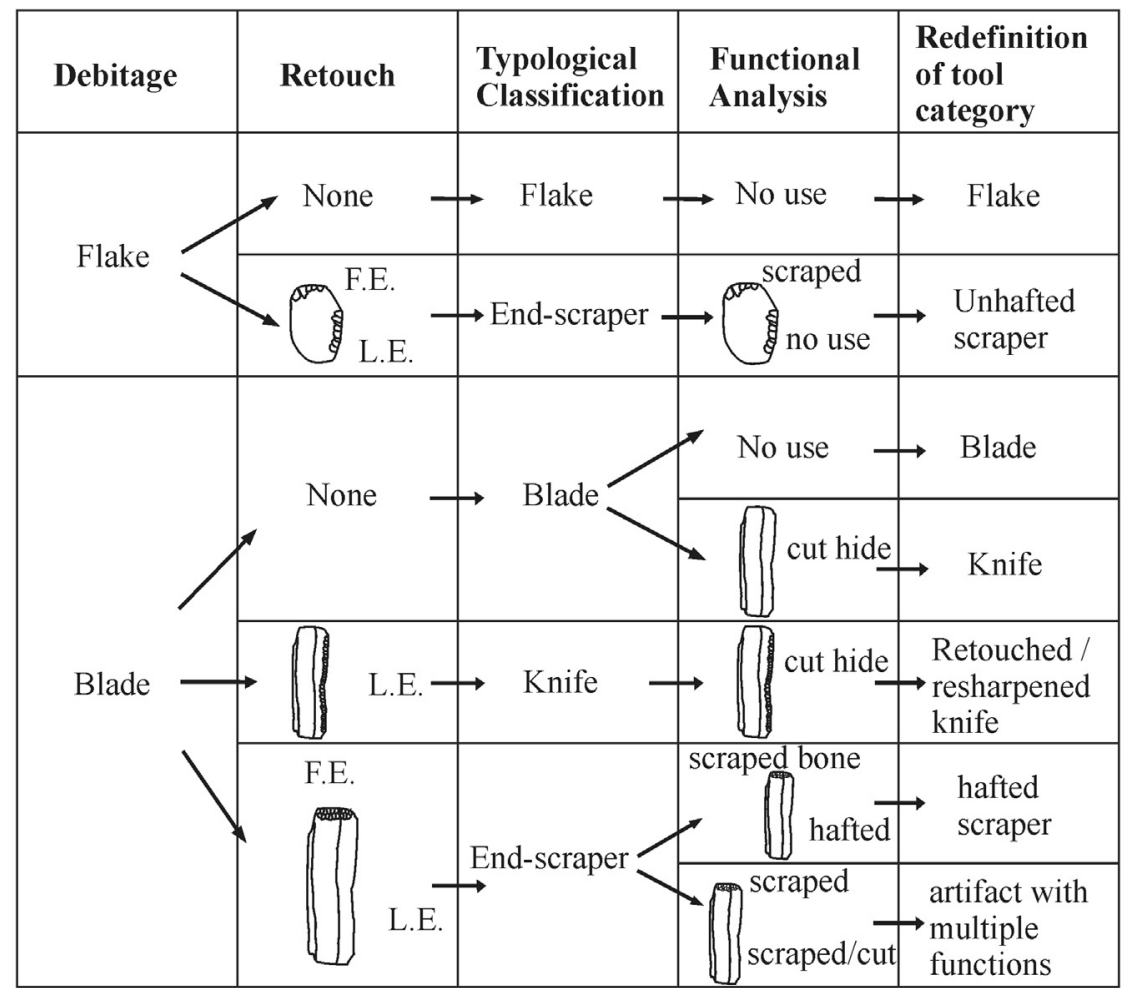

Fig. 11. Functional reinterpretation of lithic tools from the First Cultural Level of site Cueva 13 from Los Toldos. F.E.: frontal edge; L.E.: lateral edge. 
implements. Microtraces show that unretouched blades were used as knives on hide $(63.63 \%, \mathrm{n}=14)$, bone, meat and gramineae (Fig. 10). Straight edges with few sinuosities were generally used. Thus, the sharp natural edges of the blades were preferred for this task. Some of them would later be resharpened, becoming retouched knives (Fig. 11). This way, the functional study of unretouched debitage allowed us to understand how important were at the site the tasks related to cutting hide.

As a synthesis, the combination of different approaches allowed a redefinition of the typological structure and a more complex interpretation of the Casapedrense Industry. However, taking into account the abundance of raw material available in the surroundings, and the fact that many blades were used and discarded without being retouched, their production shouldn't be understood as a curated strategy. Instead of regarding it as technically unsophisticated, the Casapedrense is now considered a standardized technological system which aimed to create a large amount of functional edges. As well, this system manufactured shapes which could be used unretouched and could later be retouched to produce knives or scrapers. Some of these tools would be hafted, increasing their efficiency in certain production tasks such as the secondary processing of bones for the manufacture of goods and artifacts.

\section{Final words}

In this paper, the analysis of the lithic assemblages of three Patagonian sites was presented. The studies on the organization of lithic technology from the societies which inhabited the Central Plateau of Santa Cruz have benefited from the application of a contextual perspective. The articulation of diverse methods is useful when the researcher is trying to understand the dynamics underlying production and consumption strategies for hunter-gatherers.

The significance of these investigations lies on the integration of functional results with other studies such as typological classifications, research on operational chains, raw material availability, use of fire, and distributional studies. This integration enabled more detailed inferences which wouldn't have been possible if the diverse perspectives were applied in an isolated manner.

This integration of multiple lines of analysis showed that the final Pleistocene dwellers had diverse strategies related to the production and use of tools. Expedient strategies were usually applied as a consequence of the high availability of good raw materials. However, for certain tools which were going to be used outside the rock shelters, a curated strategy was developed.

As well, it became evident that during this time period, hearths structured the internal space of caves. Differential use of certain parts of the shelters could be linked to knapping activities in one case and to hide processing tasks in the other one, although in both sites more than one activity was performed around combustion structures.

Furthermore, the combination of perspectives encouraged the discussion of the technical capabilities of Middle Holocene inhabitants, allowing a redefinition of the typological structure in Los Toldos 13 , as well as to get a deeper understanding about production strategies and their link with functional requirements. It showed that blades production was part of a standardized technological system in which natural edges could be used or could be retouched to produce knives and scrapers, therefore taking advantage of the wide range of possibilities that these shapes offer.

Finally, taking both time periods together, this approach made visible the diversity of production and use strategies which could be implemented by hunter-gatherer societies in an area with high availability of good quality raw materials. Therefore, it becomes necessary to understand the causes and factors which triggered these changes.

Technological systems are a component of the social and economic life of individuals, enabling them to exploit resources, adapt to the environment, or to maintain an identity through social transmission processes. As more knowledge is obtained from lithic assemblages, better interpretations can be made about the social decisions that generated them and their significance in the life of a human group. Hence, an approach using multiple methods can be the starting point for a more complex understanding of past societies.

\section{Acknowledgements}

We thank Rafael Paunero, who directed the excavations in C3T1 and CDM1. Fabiana Skarbun provided us with Fig. 1 and made useful remarks about the manuscript. Two anonymous reviewers made valuable suggestions. This research was funded by CONICET and UNLP, (N688).

\section{References}

Álvarez, M., 2003. Organización Tecnológica en el Canal Beagle. El caso Túnel I (Tierra del Fuego, Argentina). Tesis Doctoral. Facultad de Filosofía y Letras, Universidad Nacional de Buenos Aires.

Álvarez, M., Vazquez, M., Piana, P., 2008. Prácticas mortuorias entre los cazadoresrecolectores del Canal Beagle: El caso de Shamakush entierro. Magallania 2 (36), 105-121.

Anderson-Gerfaud, P., 1981. Contribution métodologique a l'analyse des microtraces d'utilisation sur les outils préhistoriques. Universidad de Bordeaux I.

Andrefsky, W., 2005. Lithics. Macroscopic Approach to Analysis. Cambridge University Press, New York.

Apel, A., 2008. Knowledge, know-how and raw material - the production of late Neolithic flint daggers in Scandinavia. Journal of Archaeological Method and Theory 15, 91-111.

Aschero, C. 1983. Ensayo para una clasificación morfológica de artefactos líticos aplicada a estudios tipológicos comparativosApéndices A - C. Revisión. Cátedra de Ergología y Tecnología (FFyL-UBA), MS. Buenos Aires.

Aschero, C., 1987. Tradiciones culturales en la Patagonia Central-una perspectiva arqueológica. Comunicaciones 1ras. Jornadas de Arqueología de la Patagonia Serie Humanidades 2, 17-33.

Bamforth, D.B., 1991. Technological organization and hunter-gatherer land use: a California example. American Antiquity 56, 216-234.

Banks, W., 2004. Toolkit Structure and Site Use: Results of a High-Power Use-Wear Analysis of Lithic Assemblages from Solutré (Saône-et-Loire). University of Kansas, France.

Boëda, E., Geneste, J., Meignen, L., 1990. Identification de chaines operatoires lithiques du Paleolithique Ancient et Moyen. Paleo 2, 43-80.

Borrero, L.A., 1999. Human dispersal and climatic conditions during late Pleistocene times in Fuego-Patagonia. Quaternary International 53-54, 93-99.

Borrero, L.A., Franco, N.V., 1997. Early Patagonian hunter-gatherers: subsistence and technology. Journal of Anthropological Research 53 (2), 219-239.

Briz, I., 2004. Dinàmiques econòmiques de producció-consum en el registre lític caçador-recol.lector de l'extrem sud americà. La societat yàmana. Departament d'Antropologia Social i Prehistòria, Universitat Autònoma de Barcelona, Facultat de Lletres.

Briz, I., 2006-2007. Piedras, dinámicas, producciones y consumos: propuesta desde la Dialéctica para el análisis de los conjuntos líticos. Krei 9, 27-46.

Briz, I., 2010. Dinámicas producción-consumo en conjuntos líticos: el análisis de los conjuntos líticos de la sociedad Yámana. Magallania 2 (38), 189-211.

Cahen, D., Keeley, L., Van Noten, F., 1979. Stone tools, toolkits, and human behavior in prehistory. Current Anthropology 20 (4), 661-683.

Cardich, A., Cardich, L.A., Hajduk, A., 1973. Secuencia arqueológica y cronología radiocarbónica de la Cueva 3 de Los Toldos (Santa Cruz, Argentina). Relaciones de la Sociedad Argentina de Antropología 7, 85-123.

Cardich, A., Flegenheimer, N., 1978. Descripción y tipología de las industrias más antiguas de Los Toldos. In: Relaciones de la Sociedad Argentina de Antropología. Nueva Serie XII, pp. 225-242.

Cardich, A., Paunero, R.S., 1991-92. Arqueología de la Cueva 2 de Los Toldos (Santa Cruz, Argentina). Anales de Arqueología y Etnología Tomo 46/47, 49-97.

Cardich, A., Paunero, R.S., Castro, A.S., 1993-1994. Análisis de los conjuntos líticos de la cueva 2 de Los Toldos (Santa Cruz, Argentina). Anales del Instituto de la Patagonia. Serie Ciencias Humanas 22, 149-173.

Castro, A.S., 1994. El análisis funcional de materiales líticos por medio de la observación microscópica de huellas de uso: un modelo alternativo de clasificación tipológica. Tesis doctoral. Facultad de Ciencias Naturales y Museo, Universidad Nacional de La Plata. 
Cattáneo, G.R., 2002. Una aproximación a la organización de la tecnología lítica entre los cazadores recolectores del Holoceno Medio/Pleistoceno Final en la Patagonia Austral, Argentina. Tesis doctoral. Facultad de Ciencias Naturales y Museo, Universidad Nacional de La Plata.

Crivelli Montero, E., 1980. La industria Casapedrense (Colección Menghin). Runa, XIII (1-2), 35-57.

Cueto, M.E., 2014. Análisis de los procesos de uso de artefactos líticos en sociedades cazadoras-recolectoras. Ocupaciones correspondientes a la transición Pleistoceno/Holoceno, Meseta Central de Santa Cruz. Tesis doctoral. Facultad de Filosofia y Letras, Universidad Nacional de Buenos Aires.

Cueto, M.E., Castro, A.S., 2012. Technological and Functional Analysis of Pleistocene Components from La Maria Locality, Santa Cruz, Argentina. Current Research in the Pleistocene 149-163. Special.

Cueto, M.E., Paunero, R.S., Castro, A.S., 2012. La aplicación del análisis funcional sobre el conjunto artefactual lítico del componente temprano del sitio Casa del Minero 1 para la determinación de operaciones técnicas. In: XVIII Congreso Nacional de Arqueología Chilena. Sociedad Chilena de Arqueología, Valparaíso, Chile, pp. 519-531.

Cueto, M.E., Skarbun, F., Frank, A.D., 2014. Tecnología lítica de los cazadoresrecolectores de la meseta central patagónica. Balances y perspectivas para una propuesta de integración. In: Lourdeau, A., Viana, S.A., Rodet, M.J. (Eds.), Indústrias líticas na América do Sul: abordagens teóricas e metodológicas, (Série Estudos Contemporâneos na Arqueologia, 1). EdUFPE Recife, pp. 173-202.

Dobres, M.A., Hoffman, C., 1994. Social agency and the dynamics of prehistoric technology. Journal of Archaeological Method and Theory 1 (3), 211-258.

Durán, V., 1986-1987. Estudio tecno-tipológico de los raspadores del sitio El VeranoCueva 1. Patagonia Centro Meridional, Santa Cruz, Argentina. Anales de Arqueología y Etnología 41/42, 129-163.

Espinosa, S.L., Goñi, R., 1999. ¡Viven!: una fuente de obsidiana en la provincia de Santa Cruz. In: Goñi, R. (Ed.), Soplando en el viento... Actas de las Terceras Jornadas de Arqueología de la Patagonia. Instituto Nacional de Antropología y Pensamiento Latinoamericano y Universidad Nacional del Comahue, NeuquénBuenos Aires, pp. 177-188.

Finlayson, B., Mithen, S., 1997. The microwear and morphology of microliths from Gleann Mor. In: Knecht, E. (Ed.), Projectile Technology, pp. 107-129.

Frank, A.D., 2011. Tratamiento térmico y manejo del fuego en sociedades cazadorasrecolectoras de la Meseta Central de Santa Cruz. Tesis doctoral. Facultad de Ciencias Naturales y Museo, Universidad Nacional de La Plata.

Frank, A.D., 2012. Heat treatment of lithic artefacts in early sites from the Central Plateau of Santa Cruz (Argentina). In: Miotti, L.L., Salemme, M.C., Flegenheimer, N. Goebel, T. (Eds.), Current Research in the Pleistocene, pp. 155-158. Special Edition. Southbound. Late Pleistocene Peopling of Latin America. Center for the Study of the First Americans. Texas AyM University, Texas.

Frank, A.D., Paunero, R.S., 2009. Análisis de la alteración térmica de los restos óseos procedentes del componente temprano de Cerro Tres Tetas (Meseta Central de Santa Cruz). Evidencia arqueológica y estudios experimentales. In: Salemme, M.C., Santiago, F., Álvarez, M., Piana, E., Vazquez, M., Mansur, M.E. (Eds.), Arqueología de Patagonia: una mirada desde el último confín, 2. Editorial Utopías, Ushuaia, pp. 759-772.

Frank, A.D., Skarbun, F., Cueto, M.E., 2013. Caracterización de una fuente de xilópalo: el Bosque Petrificado de la Localidad Arqueológica La María. In: Zangrando, A., Barberena, R., Gil, A., Neme, G., Giardina, M., Luna, L., Otaola, C., Paulides, S., Salgán, L., Tivoli, A. (Eds.), Tendencias teórico-metodológicas y casos de estudio en la arqueología de la Patagonia. Buenos Aires, pp. 379-388.

Frank, A.D., Skarbun, F., Cueto, M.E., 2015. Tool production processes in lithic quarries from the Central Plateau of Santa Cruz, Argentina. Quaternary International 375, 84-98.

Frank, A.D., Skarbun, F., Paunero, M.F., 2007. Hacia una aproximación de las primeras etapas de reducción lítica en el Cañadón de la Mina, Localidad Arqueológica La María, Meseta Central de Santa Cruz, Argentina. Magallania (Punta Arenas) 35, 133-144

Geneste, J.M., 1991. Systémes techniques de production lithique: variations technoéconomiques dans les processus de réalisation des outillages paléolithiques Techniques et culture (17-18), pp. 1-35.

Gradin, C., 1980. Secuencias radiocarbónicas del Sur de la Patagonia argentina. Sociedad Argentina de Antropología XIV (1), 177-194.

Hayden, B., 1979. Lithic Use-wear Analysis. Academic Presss, New York, p. 431.

Hermo, D.O., 2008a. Los cambios en la circulación de las materias primas líticas en ambientes mesetarios de Patagonia. Una aproximación para la construcción de los paisajes arqueológicos de las sociedades cazadoras-recolectoras. Tesis doctoral. Facultad de Ciencias Naturales y Museo, Universidad Nacional de La Plata.

Hermo, D.O., 2008b. Rocas como símbolos: la selección de materias primas para puntas de proyectil en ambientes mesetarios de Patagonia. Intersecciones en Antropología 9, 319-324.

Hermo, D.O., Magnin, L., 2012. Blade and bifacial technology in mid-Holocene occupations at Deseado Massif, Santa Cruz province, Argentina. Quaternary International 256, 71-77.

Ingold, T., 1997. Eight themes in the Anthropology of technology. Techology as skilled practice. Social Analysis 41 (1), 106-138.

Keeley, L., 1980. Experimental Determination of Stone Tool Uses. A Microwear Analysis. University of Chicago Press, Chicago.

Leesch, D., 1997. Hauterive-Champréveyres, 10. Un campement magdalénien au bord du lac de Neuchâtel. Cadre chronologique et culturel, mobilier et structures, analyse spatiale (secteur 1). Neuchâtel.
Leroi-Gourhan, A., 1979. Structures de combustion et strucdures d'excavationRevista do Museu Paulintas, vol. XXVI, pp. 9-10.

Mancini, M.V., Páez, M., Prieto, A., Stutz, S., Tonello, M., Vilanova, I., 2005. MidHolocene climatic variability reconstruction from pollen records $\left(32^{\circ}-52^{\circ} \mathrm{S}\right.$, Argentina). Quaternary International 132, 47-59.

Mansur-Franchomme, M.E., 1983. Traces d'utilisation et technologie lithique: Exemples de la Patagonie. Tesis Doctoral. Universidad de Bordeaux I.

Menghin, O., 1952. Fundamentos Cronológicos de la Prehistoria de Patagonia. Runa $5,23-43$.

Miotti, L.L., 1998. Zooarqueologia de la meseta central y costa de la provincia de Santa Cruz: Un enfoque de las estrategias adaptativas aborígenes y los paleoambientes. Imprenta del Museo Municipal de Historia Natural de San Rafael, San Rafael.

Miotti, L.L., Salemme, M.C., 2003. When Patagonia was colonized: people mobility at high latitudes during Pleistocene-Holocene transition. Quaternary International 109-110, 95-111.

Miotti, L.L., Salemme, M.C., 2004. Poblamiento, movilidad y territorios entre las sociedades cazadoras-recolectoras de Patagonia. Complutum 15, 177-206.

Nami, H.G., 1986. Experimentos para el estudio de la tecnología bifacial de las ocupaciones tardías en el extremo sur de la Patagonia continental. PREP. Informe de Investigación. № 5 .

Nami, H.G., 1992. El subsistema tecnológico de la confección de instrumentos líticos y la explotación de los recursos del ambiente: una nueva vía de aproximación. Shincal 2, 13-53.

Nelson, M., 1991. The study of technological organization. In: Schiffer, M. (Ed.) Archaeological Method and Theory, vol. 3. University of Arizona Press, Tucson, pp. $57-100$.

Odell, G.H., 1981. The morphological express at Function Junction: searching for meaning in lithic tool types. Journal of Anthropological Research 37, 319-342.

Orquera, L.A., 1984-85. Tradiciones culturales y evolución en Patagonia. Relaciones de la SAA 16, 249-267.

Panza, J.L., 1994. Descripción de la Hoja Geológica 4969-II. Tres Cerros Escala 1: 250.000. Provincia de Santa Cruz. Servicio Geológico Nacional, Buenos Aires.

Paunero, R.S., 1993-94. El sitio Cueva 1 de la Localidad Arqueológica Cerro Tres Tetas (Ea San Rafael, Santa Cruz, Argentina). Anales de Arqueología y Etnología 48/49, 73-90.

Paunero, R.S., 2009a. Fogones, conjuntos líticos y funcionalidad en el componente pleistocénico del sitio Cueva 1 de Cerro Tres Tetas, provincia de Santa Cruz. In: Publicaciones del XIV Congreso Nacional de arqueología Argentina, Tomo II. Capítulo XIV: Tecnología y arqueología: enfoques en la reconstrucción de los modos de producción y uso de bienes en sociedades indígenas. Facultad de Humanidades y Artes, UNR. Rosario, pp. 419-428.

Paunero, R.S., 2009b. La colonización humana de la meseta central de Santa Cruz durante el Pleistoceno final: indicadores arqueológicos, referentes estratigráficos y nuevas evidencias. In: Salemme, M.C., Santiago, F., Álvarez, M., Piana, E., Vazquez, M., Mansur, M.E. (Eds.), Arqueología de Patagonia: una mirada desde el último confín, 1. Editorial Utopías, Ushuaia, pp. 85-100.

Paunero, R.S., Castro, A.S., 2001. Análisis lítico y funcionalidad del componente inferior de Sitio Cueva 1, Localidad Arqueológica Cerro Tres Tetas, Provincia de Santa Cruz, Argentina. In: Anales del Instituto de la Patagonia. Serie Ciencias Humanas 29, pp. 189-206.

Paunero, R.S., Castro, A.S., Reyes, M., 2007a. Estudios Líticos del componente medio del sitio Cueva 1 de Cerro Tres Tetas, Santa Cruz, Argentina: implicaciones para construir patrones de distribución artefactual y uso del microespacio. In: Morello, F., Martinic, M., Prieto, A., Bahamonde, G. (Eds.), Arqueología de Fuego Patagonia. Levantando piedras, desenterrando huesos...y develando arcanos. Centro de Estudios del Cuaternario Antártico (CEQUA). Punta Arenas, pp. 613-622.

Paunero, R.S., Frank, A.D., Skarbun, F., Rosales, G., Cueto, M.E., Zapata, G. Paunero, M.F., Lunazzi, N., Del Giorgio, M., 2007b. Investigaciones Arqueológicas en Sitio Casa Del Minero 1, Estancia La María, Meseta Central de Santa Cruz. In: Morello, F., Prieto, A., Martinic, M., Bahamonde, G. (Eds.), Arqueología de FuegoPatagonia. Levantando piedras, desenterrando huesos... y develando arcanos. Centro de Estudios del Cuaternario Antártico (CEQUA), Punta Arenas, Chile pp. $577-588$.

Paunero, R.S., Paunero, M.F., Ramos, D., 2010. Artefactos óseos en componentes del Pleistoceno final de las localidades La María y Cerro Tres Tetas, Santa Cruz, Argentina. In: Zooarqueología a principios del siglo XXI: Aportes teóricos, metodológicos y casos de estudio. Buenos Aires, pp. 459-466.

Pelegrin, J., Karlin, C., Bodu, P., 1988. "Chaînes opératoires": un outil pour le préhistorien. Technologie préhistorique. In: Tixier, J. (Ed.), Technologie préhistorique. Notes et Monographies Techniques du CRA. Edition du CNRS, Paris, pp. 55-62.

Plisson, H., 1985. Etude fonctionelle d'outillages lithiques préhistoriques par l'analyse des micro-usures: recherche méthodologique et archéologique. Tesis de Doctorado. Université de Paris I. Pantheon Sorbonne.

Podestá, M., Paunero, R.S., Rolandi, D., 2005. El Arte Rupestre de Argentina Indígena: Patagonia. Corpus Antiquitatum Americanensium. Argentina V Academia Nacional de La Histora. Unión Académique Internationale.

Roebroeks, W., Kolen, J., Van Poecke, M., Van Gijn, A., 1997. «Site J»: an early Weichselian (Middle Palaeolithic) flint scatter at Maastricht-Belvedere, The Netherlands. Paleo 9, 143-172.

Rots, V., 2010. Prehension and Hafting Traces on Flint Tools: a Methodology. Leuven University Press, Leuven, Belgium.

Semenov, S.A., 1964. Prehistoric Technology. Adams and Dart, Inglaterra. 
Skarbun, F., 2011. La organización tecnológica en grupos cazadores recolectores desde las ocupaciones del Pleistoceno final al Holoceno tardío, en la Meseta Central de Santa Cruz, Patagonia. Archaeopress. Publish of British Archaeological Reports, Oxford.

Skarbun, F., Frank, A.D., 2011. Organización espacial intrasitio durante el Pleistoceno final en la Meseta Central de Santa Cruz. In: Evidencias del sitio Casa del Minero 1. Relaciones de la Sociedad Argentina de Antropología XXXVI, pp. 289-313.

Skarbun, F. Frank, A.D., Cueto, M.E., Paunero, M.F. Rosales, G., 2007. Análisis de tecnología lítica del Sitio Casa del Minero 1, Meseta Central de Santa Cruz. In: Morello, F., Prieto, A., Martinic, M., Bahamonde, G. (Eds.), Arqueología de FuegoPatagonia. Levantando piedras, desenterrando huesos... y develando arcanos. Centro de Estudios del Cuaternario Antártico (CEQUA), Punta Arenas, Chile, pp. 589-600.

Skarbun, F., Páez, G., 2012. Análisis de secciones delgadas de materias primas provenientes de la Localidad Arqueológica La María, pp. 247-260. Meseta
Central de Santa Cruz, Argentina. Comechingonia. Revista de Arqueología. Número 16 (Primer semestre 2012).

Terradas, X., 2001. La gestión de los recursos minerales en las sociedades cazadorasrecolectoras. Consejo Superior de Investigaciones Científicas, Madrid.

Terradas, X., Gibaja, J., 2001. El tratamiento térmico en la producción lítica: el ejemplo del Neolítico Medio catalán. Cypsela 13, 31-56.

Tixier, J., Inizan, M.L., Roche, H., 1980. Prehistoire de la Pierre taille. Circle de Rechearches et d'etudes prehistoriques, Antibes, France.

van Gijn, A., 2003. The Ninevite 5 chipped stone assemblage from Tell Leilan: preliminary results. Subartu IX, 401-416.

Vaughan, P., 1981. Lithic Microwear Experimentation and the Functional Analysis of a Lower Magdalenian Stone Tool Assemblage. Tesis de Doctorado. Universidad de Pennsylvania.

Vila, A., 2006. Propuesta de evaluación de la metodología arqueológica. In: Etnoaqueologia de la Prehistoria: mas allá de la analogía. Treballs d' etnoarqueologia, 6. CSIC, Madrid, pp. 61-76. 